\title{
The lonely antipope - or why we have difficulties classifying Pedro de Luna [Benedict XIII] as a religious individual
}

\section{Object of the study}

This paper presents a case study of a late medieval, although pre-modern, person within the context of the Latin (Western) Great Schism. The geographical focus is on south-west Europe, or, to be more precise, the South of France and the North of the Iberian Peninsula. The example leads us to reflect on a special problem with the concept of individualisation, a specific problem of perception, description, and terminology, which results in the invisibility of a special kind of individualisation. The chapter will conclude by proposing a term that can mark out this specific invisibility in a visible manner, so that the problem is, at least, included in the research matrix.

Two points should be mentioned in advance. First, the case might be somewhat surprising. The person to be analysed was a pope: Pedro Martinez de Luna, known also as Benedict XIII. A pope (or 'the pope') could figure well as the opposite of what is usually assumed to be interesting within the process of individualisation. It is important to recognise that the object of this case study is the natural person (this pope), not the office (the pope).

A second point concerns the meaning of the term 'religious'. Throughout this paper, the meaning will be mainly judicial. Pedro de Luna was a canonist, a specialist in Canon Law, and, probably for this reason, his ecclesiology, his understanding of heresy and 'orthodoxy' and also his own statements and actions according to or differing from his contemporaries, were mainly judicial. So the term 'religious' has a meaning not so much in a theological sense but in the sense of 'divine law'. Therefore, law is not only the limit of religious freedom or the shelter of a wide range of religious options: i.e. it functions not only as the frame but as the religious field itself. But, in turn, the term 'divine law' (ius divinum) will not be used here in precisely the same sense it carries in the discourse of canonists. Within that context, the phrase is used as a terminus technicus and forms the antonym to 'ecclesiastical law' (ius mere ecclesiasticum). ${ }^{1}$ In the present

1 Ecclesiastical law is made by human beings and it is the outcome of the work of humans who tried to listen to God but were forced to use human language to express the concrete norm, or 
chapter, however, no opposition to ecclesiastical law is intended. Here, the term just makes clear that, as seen from the Christian Canonistic perspective, religious law is really part of the relation with God as a transcendent being. Most canoni$\mathrm{cal} /$ legal norms refer largely or wholly to questions about the social aspect of the mystical body of Christ and are used to regulate the life of the Church in a social way. They are 'religious' in a strict sense but they are not 'unquestionably plausible' as, in theory, divine law is in the sense of the terminus technicus.

\section{The life of Pedro de Luna/Benedict [XIII]}

Pedro Martínez de Luna (1342-1423) is known today primarily as the pope of the obedience of Avignon from 1394-1417/23. ${ }^{2}$ His papacy was the longest of the Great Western Schism. Despite this, he did not become as well-known as he might have done because he was considered by the later tradition to be an antipope. As such, he was given significant weight neither in secular historiographical research contexts, where popes of the Schism were written with brackets around the ordinal numeral ('Benedict [XIII] / Pedro de Luna') or not ('Benedict XIII / Pedro de Luna') and freed from the question of the legitimacy of their succession, nor in theological contexts, which tried to draw a valid line from Peter the Apostle through the 'real' popes of 'Rome' to the present, where his inclusion would have meant his becoming part of the long tradition of popes, who are, thanks to the office, always an object of fame and curiosity. ${ }^{3}$ Nor did Benedict become an object of research as simply an interesting person, at least not outside his native Spain (Puig i Puig 1920; Moxó y Montoliu 1986; Parrilla, Muñiz, and Caride 1987; Sesma Muñoz 1994;

even had to regulate something which is untouched by questions or topics of divine law. Divine law, on the contrary, has to be made by God. For example, the substance of the Ten Commandments will be seen as divine law. Even there, seen from the Christian Canonistic perspective, one must distinguish between the order God gives and the expression of the order through the medium of human language. Several norms, judicial or moral, are nevertheless seen as being divine law, as, for example, the indissolubility of sacramental matrimony (Aymans 1996).

2 The date 1417 is usually seen as the end of the schism, as it marks the deposition of Benedict XIII by the Council of Constance. However, since he did not accept this deposition, and because there remained loyal churchmen with him who elected a successor, there is another strong tradition of dating the end of the schism later. According to this reading of events, the end of Benedict XIII's papacy is the date of his death: Moxó y Montoliú 2006; Alanyà i Roig 2014.

3 The historiography of papal history was initially understood as a task to be pursued like a chronicle, starting with the Liber pontificalis. After the Protestant Reformation this changed, as historiography became an important political and theological issue. For a splendid introduction to the conditions under which this historiography developed, see Fuhrmann 1989. 
Centro de Estudios Bilbilitanos Institución 'Fernando el Católico' 1996; Pereira Pagán 1999; Suárez Fernández 2002, etc.). Research on the time of the Schism and the Council of Constance had little to say about him, with some exceptions in the works of writers from Germany (e.g. Ehrle 1892, 1900a, 1900b; Seidlmayer 1933; Girgensohn 1989; Langen-Monheim 2008; Jaspert 2014; Schwedtler 2018, Müller-Schauenburg 2018) and France (Pillement 1955; Millet 2009).

De Luna was born as the son of a noble family (Schwedtler 2018, MüllerSchauenburg 2018), at a small castle in the city of Illueca in Aragon (Pereira Pagán 1999, 31-40). In Aragon some relics of his body are kept today in a small shrine (Parrilla, Muñiz and Caride 1987, 157f.). He was familiar with the Iberian political and cultural situation and well connected to the noblemen throughout the whole region, and familiar too with the 'multi'-religious situation, in which Jews, Muslims and Christians lived in close proximity. After a military education, he studied Canon Law at the University of Montpellier, where most students from Aragon went at that time. He became a professor at the same university, where he taught the Decretum Gratiani (Verger 2004).

By the time De Luna was born, the papacy had already been in Avignon for thirty years. In earlier phases of historiography, this shift of the papacy to Avignon was ill-famed as a 'Babylonian captivity' of the Church and both the King of France and the pope were blamed for creating a wrongful dependency of the papacy upon the French crown. Today's historiography tells a very different story. French historians, followed by the international community, were the first to emphasise the cultural impact of the Avignon papacy on Europe as a whole and also on the Latin Church (Hamesse 2006; Favier 2006 et al.). The period of Pedro de Luna's childhood was already seeing signs of the decline of the papal palace as a cultural centre of the Latin world. However, the papal court's effects were still present, the intellectual situation vibrant. Within these years, the ecclesiology of the late medieval Latin Church took its most important developmental steps and the influence of mystical, as well as philosophical, traditions came to the attention of the popes - here we need only mention the struggles with such noted 'heretics' as Eckhart, Marsilius of Padua, William of Ockham, and the Cathars.

Pedro de Luna was created cardinal in 1375 by Gregory XI in an atmosphere that was filled with expectancy at the imminent return of the papacy to Rome. The following year, he accompanied the pope back to the city with which the papacy is most identified but it appears that this 'come-back' was by no means easy. In contrast to attitudes at Avignon, the pope was not welcomed by the populace and violence from clergy of his party made things even more difficult. In 1377 the pope had to flee to Anagni, near Rome, for some months, staying there from May to November. Less than twenty months later Gregory XI died on the 28th of March, 1378. The election of a new pope took place in Rome that April, albeit under very 
difficult circumstances due to threats from the public. Eventually, a second election took place but the pope who had been elected in the first process, Urban VI, refused to give up his position. Thus the Great Schism began (Seidlmayer 1940).

Pedro de Luna was among the group of cardinals who returned to Avignon with Clemens VII, the winning candidate of the second election. During the following years, de Luna made his career as a cardinal. His main mission was the winning of territory for the obedience of Clemens VII. He had some significant successes both in France and, especially, in the Iberian Peninsula. The first reason for his success was his familiarity with the Iberian nobility and church, and the second was his clear thinking and argumentative abilities.

When Clemens VII died in 1394, Pedro de Luna was elected as his successor. Everybody's wish was to end the schism and he seemed to be the one with the wish and the ability to do so. But there was a change of atmosphere in the relationship with the French crown. Charles VI of France no longer supported Benedict XIII, dissent arose, and there was a military attack on the papal palace in Avignon, during or after which the pope and his curia were imprisoned in the palace. After seven months of imprisonment Benedict XIII eventually managed to flee. Once he was free again, the atmosphere changed somewhat in his favour. He took up a kind of 'mobile papacy' based on a series of temporary locations, moving with his curia mainly along the coast between the Pyrenees and Liguria.

The Council of Pisa in 1409, organised by cardinals of both obediences, was initially viewed sceptically by de Luna/Benedict XIII for canonistic reasons. Nevertheless, he sent a delegation and was ready to participate in the proceedings. But the delegation was treated very badly and even threatened by the Council (Brandmüller 1990). This experience, and the broader outcome of the council a third pope and Benedict XIII's deposition and excommunication by the cardinals - changed Benedict's disposition and his willingness to strive for union. The personal danger for him grew and so, in 1411, he finally moved to Peñiscola, a small castle at the coast between Barcelona and Valencia. This castle became the new (and last 'Avignonesian') papal palace. The radius of his papal activities became, seen from a European perspective, more and more local. The king of Aragon and the clergy remained loyal and the obedience, despite becoming smaller, continued to function well, at the beginning at least. A deep break came with the Council of Constance and its temporal dependency in Perpignan in 1415 (which has been neglected in research and historiography for a long time), when the emperor-to-be Sigismund of Hungary came to see Benedict XIII to 'negotiate' with him (Jaspert 2014, 119-41; Catafau, Jaspert and Wetzstein 2018). In fact, the only option Benedict XIII was given was to abdicate unconditionally. After the unsatisfactory result of the Council of Pisa, and being a canonist, this option was 
not one Benedict could take seriously. When the King of Aragon and Sigismund both tried to press a decision on him, Benedict left the place with his curia and returned to Peñiscola.

The result was a consensus and contract between the two kings, effectively dictated by the more powerful ruler. A part of the regional clergy became part of the contract party, another part tried to stay loyal to Benedict XIII. In Constance, Benedict was deposed (again) by the Council in 1417. But he lived on until 1423, governing in Peñiscola, and passed his papacy on to a successor who managed, in 1429, what had eluded Benedict: the ending of the schism in a legal way, without the risk of more chaos, and to give up papacy while being, from his own point of view, responsible for the perpetuation of the apostolic succession (Suárez Fernández 2002, 307). Up until his death, Benedict XIII had a small, functioning curia and was, in fact, a pope, albeit one separated from almost the whole of the 'rest' of the church. He spent the period living in a small palace, surrounded by the sea, and indulging his fondness for books. His library is known of and discussed by specialists of this late medieval period and of the history of books in general (Jullien de Pommerol and Monfrin 1991; Egger 1995; Planas Badenas 2014; Löffler 2018 et al). Not so well known is his public disputation about religion with jewish scholars, which dates to just before the Council of Constance, although it has been topic of some research (Pacios Lopez 1957; from Jewish side for example: Talmange 1985; Rauschenbach 2002; Cohen 2013). The outcome and meaning of this disputation is very problematic from today's perspective (Jörg 2011). Nonetheless nobody doubts that he was the only medieval pope who initiated and personally took part in a public disputation with Jews, had an inventive concept of the union of Jews and Christians, and was very much interested in and familiar with Jews as well as Muslims.

\section{A person of integrity, non-violence and law - condemned, excluded, secluded}

We can observe four aspects of Benedict's personality which mark him out as a possible object of research on religious individualisation in his period. The first is a part of his character: he remained a person of integrity while being condemned by 'the church'. Many of his contemporaries, whether of his obedience or not, gave reports or testimonials describing, and even enthusing about, this quality of his character and his behaviour in general (with many quotations: Immenkötter 1976). This pope always went his own way within the church and this characteristic independence of mind became more pronounced, rather than 
less, when he became a person with responsibilities for important decisions within the institution. To give one example: during the election of 1376, de Lunas behaviour contrasted markedly with that of the other cardinals (Seidlmayer 1933). He remained calm and reasonable during the violent election of Urban VI and also remained calm regarding the outcome of the election. Initially, he refused to flee with the others from Rome to Anagni, waiting instead to study the situation, acquire and accurate the picture, and draw his own conclusions. Eventually he went to Anagni, alone, with the aim of convincing all his colleagues of his opinion. Meeting them, afraid as they were and ready to execute panic-fuelled and inconsiderate proceedings, he again showed himself to be a listening and reasoning person. He was ready to be convinced by them concerning their fear. He did not just deliver his own opinion or shout loudly enough to be the winner of the discourse; rather, he reacted to what he was seeing and tried to find a legal way to keep the church together. He was not a notorious loner, however. His strong will to think with his own mind was noticeable in the eyes of contemporary eyewitnesses.

In Medina del Campo, the King of Aragon organised an interview of the participants of the elections in order to come to his own opinion regarding the elections and who should be recognised as the legal pope. De Luna alone testified, stating that he had not been afraid during the first election (which would have been a legal foundation for the second) but that he had subsequently been convinced by the fear of the other cardinals, and only then he has been prepared to countenance a second election (Seidlmayer 1933, 211f.).

Later in life, too, Benedict XIII was never willing to be pressed. He always insisted on forming his own opinion and acting in accordance with his own beliefs. Even while suffering the loss of territory, he remained faithful to his favourite way of finding a solution: through argument. Attractive, intelligent, never boring, and upright, he was a magnet to interesting contemporaries and they took pleasure in his presence. When politics took another turn, he was left by most of them. Hardest of all was his abandonment by the King of Aragon, whom he had helped so much. Despite these setbacks, he did not threaten anybody (Müller-Schauenburg 2018) and just continued on his own way. When the mission from the Council of Constance came to announce to him his deposition, he remained calm and reasonable (Brandmüller 1997, 266-8). In contrast to so many other popes of medieval (and other) times, not a single rumour of nepotism, the breaking of moral rules or vows was ever told, or none at least that was found to be true: The accusation that he called demons (see also Boudet 2009), aired by the Council of Pisa, was unfounded and was not repeated at the Council of Constance. That he remained such a person, even while being condemned by, so to speak, the 'rest of the Christian world', was not the outcome of his lack of 
power but of a high ethical standard. He did not change his behaviour when he lost power and influence but remained as he had been from the beginning, as is evident, for example, in the context of the election of 1376.

The crucial question regarding the interpretation of Benedict XIII's behaviour within the matrix of religious individualisation is that of his own understanding and motivation for this behaviour. We do not have sources such as diaries that contain reflections on these decisions. Because of this, if we wish to look further, we must of necessity turn our eyes towards his library, to the books he owned and read, and to the people with whom he talked. As has already been mentioned, the papal court of Avignon had become a centre of culture at that time and, contrary to what is sometimes assumed, the growing humanism of the period had something like a centre or cluster not only in Italy but also in Avignon. Being an intelligent and interested person, Benedict XIII made contact with humanists (Ornato 1969).

Nicolas de Clamanges, the famous French humanist, was for a long time part of Benedict's court and also acted as his librarian. Remarkably, not in the 'libraria magna' but in the personal small working papal library, dating to his years in the papal palace in Avignon, we can find a collection of manuscripts containing works by Petrarch (Jullien de Pommerol and Monfrin 1991, 132). For a while at least, Benedict must have had a special interest in this author. It is very likely that he was attracted by Petrarch's melancholic view of loneliness, especially the inner loneliness of the person who tries to follow the way of the mind. This sense must have been particularly prominent for him as he suffered through the decline in French support.

This atmosphere of melancholic and tragic loneliness may have been very important for Benedict XIII, as a pattern for understanding his own situation and, perhaps, also important for the few people who remained loyal to him as part of his small papal curia until his death. Literature gave nourishment and positive value to this type of existence. One has to follow one's way, no matter whether or not the crowd accepts it or is even willing or able to understand it, and consolation can be received from the beauty of the truth - these assumptions must have been decisive for Benedict XIII. He also possessed an exemplar of the 'Dialogus' of William of Ockham. Ockham's teaching of the church of the 'faithful remnant' in the right way to God must also have been important to Benedict XIII. The manuscript had already been part of his library when he was still a cardinal (Ehrle 1890, 555). It was brought to Peñiscola to become part of the papal library at his new palace (Jullien de Pommerol and Monfrin 1991, 489). Third, and in addition 
to Ockham's theological perspective, the tradition of consolationes was foundational for Benedict XIII's positive attitude towards being left alone with the truth. ${ }^{4}$

What is really most peculiar regarding Benedict's behaviour is his non-violent reaction to the threats he had to suffer. This was very closely related to his reading of the Stoics and, especially, to the perspective of the 'consolatio-literature'. Benedict XIII took his time to think about each situation and he always took his next step with a sober mind. When his life was in danger, he simply changed his location immediately and calmly, but he never started a precipitous and violent defence. He suffered what was done to him, not moving one inch away from what he assumed to be the right way and the truth for the church. ${ }^{5}$ Benedict may have been not a saint, and nor did he only bring peace. It is questionable, for example, whether his meticulous sticking to the law or his idea of bringing the Jews closer to the Christian community did not have an enormously disruptive effect, as it has been said also regarding the disputation of Jews and Christians above mentioned (Dahan 1990, 359). But his reaction when being injured himself was always calm and sometimes ironic. These ironic dicta, in particular, have been taken by some historians as proofs that he was detached from any serious connection with reality anymore, yet in fact, they are not. Benedict never mixed arguments with jokes. Where negotiation was concerned, he stuck to arguments and to nothing else. But he had room for both. When he called the rock of Peñiscola his 'Arche Noe' (Seidlmayer 1933, 206), excommunicating the rest of the world - a compari-

\footnotetext{
4 There is a Consolatio which was for a long time attributed to Benedict XIII. However, today we can be certain that he was not the author (the real author was Iohannis de Tambaco,), although the reason for this (wrong) medieval adscription of the text to him through two medieval manuscripts, is an open question. The simple fact of the reference to the similarity with the described situation Boethius/Johannes/Pedro does not explain the adscription: an image of his one with arms, and one from his nephew, a close relative, just seven years after his death - if the adscription had been an image of his ridiculous error, this had been impossible. The questions, given by Stegmüller concerning the process and motivation, are still open (see Stegmüller 1963). At least it must had been imaginable by people very familiar with him, maybe himself, that this could have been his perspective and the text be composed by him. One manuscript puts this text in context with Cicero. Also interesting is that it is containing strong reference to Seneca (rules of the Imitatio Christi). 5 This attitude could be described as related to the perception of 'Leidensmystik' (pointed out in the context of Dietmar Mieth's work on Meister Eckhart) which was new at his times, with the parallel characteristics of being not ascetic, being unsought and unwanted, having its origin only outside of the individual, not abnegating the empirical situation by the average of theological reflection, and - we can only assume, be the lack of the diary telling s.th. like this - felt as a duty in obedience to God (see Mieth 2004, 136-49). There are some typological parallels with the case of Riccarda Suitner, who speaks about radical pacifism and the diversity of American sects, which can be considered 'in an apparently paradoxical way [...] simultaneously an expression of individualisation and conformity', see her contribution to this publication.
} 
son which has often been said to describe an old man who is not to be taken seriously any more - he was in fact only expressing, as a canonist, the consequence of the separation of all the others from him, in as far as he might be the true pope. The image conveys his feeling that God was with him in his increasing seclusion in that place, giving him shelter while a big battle was happening all around him. Really, like Ockham, Benedict XIII was able to imagine a true church held and built by just a few souls, perhaps only one soul, going on in the right way without any kind of 'power' in a secular sense of the term. And although at the end of his life more or less nobody in Europe was ready to affirm his position, he carried on in what he assumed to be his way until the end.

Benedict XIII never restricted the judicial singularity of the papal office. But he restricted himself within the limits of canonistic options (which are less extensive than the theological options which came after the schism), and he never thought himself to be omnipotent or as having any similar status. While a pluralistic option was not part of his concept of the papacy, his adherence to the 'way of arguments' (known as via discussionis or via conventionis) as a way of leading the church means that, at least at the level of theory, he was familiar with, and even assumed, a plurality of possible positions. His manner of staying faithful to his convictions regarding religious law and his own ecclesiological standpoint, even while losing not only his real political power but also his friends and supporters, is more than surprising and is best explained by looking at the books in which he was interested.

\section{Four reasons for invisibility within the matrix of 'types of individualisation'}

So, we have a person who separated from the church because of his own, careful thoughtfulness. Why is it so difficult to describe this person within the framework of religious individualisation? There are four main reasons, which disclose a paradox, namely that there are some individuals in history with little or no chance of becoming a 'religious individual', although they perform perfectly some essential elements of a standard individualising career. We will look at each of the four in turn.

The first reason is that the counter-part of deviation in this case is difficult to grasp. It is neither institutional nor normative. Benedict XIII was elected as the pope and he never ceased to define his life, office, and mission in these terms. Seen from his perspective, there was only a de facto, but not a de jure crack in his relationship with the Roman Catholic Church. His reference community did not 
change at all. ${ }^{6}$ In addition, Benedict was a canonist through and through and it was partly his fidelity to legal procedure that made him so lonely. He did not act against laws. He did not and could not refuse to obey a religious authority, since he himself was, in his own eyes, the highest authority. So in terms of a deviation, one can only describe the separation between numbers or groups of people. Perhaps with the perspective of history, one can identify a process of privatization - but without any relevance to anybody, at least. There has not been any long-term effect, no new theology or something like that. ${ }^{7}$ It is impossible to identify a 'deviation' of this individual, neither from an institution nor from norms. The 'otherness' of this person is in-visible.

The second reason is similar to the first: There is a lack of self-characterisation as a deviating subject. Benedict XIII wanted to be traditional, regardless of the fact that few remained faithful to him who shared his understanding of tradition. The zero-point of the measure for deviation was himself. From his point of view, all the others were deviating. They were heretics. This individual in defence had a perfect fall-back position. He tried, with all his power, to be an institutional person. Office and persona came in tension and relation in a very striking way. Benedict XIII stepped, so to say, out of his original persona to defend an office with which he himself was completely identified.

The third reason, again closely related, is: there is a lack of perception by others as a deviating subject in an emphatic manner, positive or negative, and a lack of institutionalisation and historical reception of him in terms of individualisation. No group followed in his path and no process of institutionalisation took him as a point of reference. In short, there was no stabilisation for long, no standardisation, no regime following him, and therefore there was never anybody who included Benedict XIII's story, at least in general terms, into his or her own story of individualisation, institutionalisation, or de-institutionalisation. With the dissolution of his former institutional environment when the schism ended in 1429, and the lack even of an 'honouring' resistance against his position, the complete neglect and overwriting or replacement of this institutional form was complete. We do not

6 One might describe the 'heretics', i.e. anybody not accepting him as pope, as the counter-part of the deviation from which he distanced himself.

7 During Benedict XIII's time as pope there was an emergence of spaces of choice or freedom, both for the believer and for theologians of the time within his obedience. This was an effect of his ecclesiology. He did not mind if theologians were doing or thinking things that seemed to be quite new regarding their teaching in philosophy, Christology, the status of the Mother of God, and other such topics which had been objects of struggle for a long time and became so again afterwards. To him, only the administrative 'orthodoxy' was relevant. His indifference to theological questions, or - emphatically - his 'stoic' relation towards dogmatic struggles can be seen as an effect or a result of the 'legalistic' individualisation of Pedro de Luna. 
have any appropriation ('Aneignung', see Matthias Engmann on Kierkegaard in this publication), any recipient. This case makes it obvious that there is not only a paradoxical characteristic of religious individualisation that as soon as it affects religious groups or prompts their formation, dynamics of normativisation and standardisation may ultimately congeal into a collective phenomenon (see the general introduction by Fuchs et al. in this publication). On the contrary: if formation of new groups or discourses and standardisation does not happen in any way, then there will be no visible phenomenon at all, at least not one of relevance. The notion of 'relevance' could also be seen as a crucial point. In the case of Pedro de Luna, we have to mention the emerging Spanish and Catalan research interest in him now, which is developing now partly for political reasons. So there is not simply 'nothing at all'. How relevant is a group of recipients who are, again, deviating from the mainstream of research? Additionally, a kind of 'third order relevance' can be identified regarding the question the case raises for the concept of religious individualisation and for the historiography of the time of the Schism as it is usually told.

To summarise: There is a general problem with describing individualisation as deviation as far as the leading figure of a traditional religious institution is concerned. And there is a special, second problem, visible particularly in this case, of how to grasp an unsuccessful 'individual' who was not even admired by those who followed his path a little later on, i.e. the popes after the final union of with the remaining papal curia from Peñiscola, taking up for example his support of the university of Salamanca, or the canonists of the school of Salamanca - who, quite the reverse, deliberately avoided referring to him. This problem may be a specific or typical problem within the late middle ages, during which period the interstices between what emerged as 'modernity' and what remained 'medieval' were more complex than historiography was for a long time willing to concede.

This reveals the necessity of applying an inverted frame of the concept of individualisation, in order to register - and not to miss in research, as well as in historiography written by an institution itself - such possibilities as the case of a person who in fact is unwillingly deviating from a religious institution of which he simultaneously believes himself to be the solitary leader, granted that status by the will of God. What the case of the lonely antipope asks is for us to name his type of individualisation, so that it may be part of the research matrix. I propose to call this type of individualisation 'missed individualisation'. 


\section{5 'Missed individualisation'}

'Missed individualisation' does not mean - just to underline directly the most likely misunderstanding - that Pedro de Luna failed to become an individual. The failure and 'missing' are elements of the history of its reception. Missed individualisation is a lack of perception, under very special conditions, by the contemporary as by the later-born. A social precondition of this type of individualisation is the identification of the person with an office (what we would perhaps call within a modern framework an 'impersonal' position), and the type of office itself. In the case of Benedict XIII, his contemporaries were not interested in him as a model of a religious plurality, which seemed to be desirable. Nevertheless, a leading figure in medieval times was, seen from the legal point of view, strong, much more endowed with internal law (in German: 'Eigenrecht'). There was not in every case such a big contrast between the legal frame and the 'individual', as we would assume from the modern point of view. Research on religious individualisation, having its origins in specific modern ideas that are now to be extended into new spaces and periods, could be in danger of missing such cases if it does not draw them out with special effort. This notion, this kind of process and dynamics of individualisation, must be considered with special attention. These cases will probably never become the most convincing examples within the frame: they are truly 'missed'. But it seems to be important, at least, to identify them as well.

\section{References}

Alanyà i Roig, Josep. 2014. El cisma de Occidente y las vistas de Morella: Historia y documentos, 1378-1429. Morella, Castellón: Ayuntamiento de Morella.

Aymans, Winfried. $1996^{3}$. 'Art. Ius divinum - ius humanum, Kirchenrechtlich', Lexikon für Theologie und Kirche 5. Sp. $698 \mathrm{f}$.

Boudet, Jean-Patrice. 2009. 'Le “pape de la lune” et la magie'. In Hélène Millet (ed.). 177-84.

Brandmüller, Walter. 1990. 'Die Gesandtschaft Benedikts XIII an das Konzil von Pisa'. In Papst und Konzil im großen Schisma (1378-1431): Studien und Quellen, ed. idem, Paderborn: Schöningh. 42-70.

Brandmüller, Walter. 1997. Das Konzil von Konstanz, 1414-1418 II. Paderborn: Schöningh.

Catafau, Aymat, Nikolaus Jaspert and Thomas Wetzstein (eds.). 2018. Perpignan 1415: Un sommet européen du Grand Schisme d'Occident. Geschichte und Kultur der Iberischen Welt 15. Berlin - Münster: LIT-Verlag.

Centro de Estudios Bilbilitanos Institución ‘Fernando el Católico' (ed.). 1996. Jornadas de Estudios. VI Centenario del Papa Luna 1394-1994. Celebradas en Calatayud-Illueca, 1994. Calatayud, Zaragoza: Cometa.

Cohen, Jeremy. 2013. 'Interreligious Debate and Literary Creativity: Solomon ibn Verga on the Dispute of Tortosa’, Jeswish Studies Quarterly 20.2. 159-81. 
Dahan, Gilbert. 1990. Les intellectuels chrétiens et les juifs au moyen âge. Paris: Édition du Cerf. Egger, Christoph. 1995. 'Handschriften aus der päpstlichen Bibliothek von Avignon-Peniscola: Beobachtungen zur Uberlieferungsgeschichte der theologischen Schriften Papst Innocenz III', Römische Historische Mitteilungen 37. 81-96.

Ehrle, Franz. 1890. Historia bibliothecae Romanorum pontificum tum Bonifatianae tum Avenionensis: Enarrata et antiquis earum indicibus aliisque documentis illustrata. Roma: Typis Vaticanis.

Ehrle, Franz. 1892. 'Neue Materialien zur Geschichte Peters von Luna (Benedicts XIII.)', Archiv für Literatur- und Kirchengeschichte des Mittelalters 6. 139-308.

Ehrle, Franz. 1900a. 'Die kirchenrechtlichen Schriften Peters von Luna (Benedikts XIII.)', Archiv für Literatur- und Kirchengeschichte des Mittelalters 7. 515-75.

Ehrle, Franz. 1900b. 'Neue Materialien zur Geschichte Peters von Luna (Benedicts XIII.) (Fortsetzung)', Archiv für Literatur- und Kirchengeschichte des Mittelalters 7. 1-310.

Favier, Jean. 2006. Les papes d'Avignon. Paris: Fayard.

Fuhrmann, Horst. 1989. 'Papstgeschichtsschreibung: Grundlinien und Etappen'. In Geschichte und Geschichtswissenschaft in Italien und Deutschland: Wissenschaftliches Kolloqium zum hunderjährigen Bestehen des Deutschen Historischen Instituts in Rom (24.-25. Mai 1988), eds. Arnold Esch and Jens Petersen, Tübingen: Niemeyer. 141-91.

Girgensohn, Dieter. 1989. 'Ein Schisma ist nicht zu beenden ohne die Zustimmung der konkurrierenden Päpste: Die juristische Argumentation Benedikts XIII', Archivum historiae pontificiae 27. 197-247.

Hamesse, Jacqueline (ed.). 2006. La vie culturelle, intellectuelle et scientifique à la cour des papes d'Avignon. Textes et études du moyen âge 28. Turnhout: Brepols.

Immenkötter, Herbert. 1976. 'Ein avignonesischer Bericht zur Unionspolitik Benedikts XIII', Annuarium historiae conciliorum. Internationale Zeitschrift für Konziliengeschichtsforschung 8. 200-49.

Jaspert, Nikolaus. 2014. 'Das aragonesische Dilemma. Die Heimat Benedikts XIII. zwischen Obödienzstreit, herrschaftlichem Umbruch und internationaler Verflechtung'. In Das Konstanzer Konzil als europäisches Ereignis: Begegnungen Medien Rituale, ed. Gabriela Signori, Ostfildern: Thorbecke. 107-41.

Jörg, Christian. 2011. 'Reformdiskussion und Abgrenzung: Christen und Juden in Augsburg zur Zeit des Basler Konzils'. In Integration und Desintegration der Kulturen im europäischen Mittelalter, eds. Michael Borgolte et al. Europa im Mittelalter 18, Berlin: Akademie Verlag. 68-81.

Jullien de Pommerol, Marie-Henriette and Jacques Monfrin. 1991. La bibliothèque pontificale à Avignon et à Peñiscola pendant le Grand schisme d'Occident et sa dispersion: Inventaires et concordances. 2 vols. Collection de l'École française de Rome 141. Rome/ Paris: École française de Rome/de Boccard.

Langen-Monheim, Barbara von. 2008. Un Mémoire Justificatif Du Pape Benoît XIII: L'Informatio Seriosa: Étude De Ses Reformulations, De 1399 Aux Actes Du Concile De Perpignan (1408). Etudes roussillonnaises, revue d'histoire et d'archéologie méditerranéennes 23. Canet: Trabucaire.

Löffler, Anette. 2018. 'Bücher Benedikts XIII'. In Der Papst und das Buch im Spätmittelalter, ed. Rainer Berndt. Erudiri Sapientia 13. Münster: Aschendorff. 275-527.

Mieth, Dietmar. 2004. Meister Eckhart: Mystik und Lebenskunst. Düsseldorf: Patmos.

Millet, Hélène (ed.). 2009. Le Concile de Perpignan (15 novembre 1408-26 mars 1409): Actes du colloque international (Perpignan, 24-26 janvier 2008). Canet-en-Roussillon: Trabucaire.

Moxó y Montoliu, Francisco de. 1986. El Papa Luna: Un imposible empeño. Estudio políticoeconómico. Zaragoza: Editorial Libreria General. 
Moxó y Montoliú, Francisco de. 2006. El Papa Luna, un imposible empeño. La legitimidad de Benedicto XIII. Benicarló: Centre d'Estudis del Maestrat.

Müller-Schauenburg, Britta. 2018. 'Perpignan 1415: The negotiations and the role of Benedict XIII'. In Aymat Catafau, Nikolaus Jaspert and Thomas Wetzstein (eds.). 559-574.

Ornato, Ezio. 1969. Jean Muret et ses amis Nicolas de Clamanges et Jean de Montreuil: Contribution à l'étude des rapports entre les humanistes de Paris et ceux d'Avignon (1394-1420). Centre de recherches d'histoire et de philologie de la IVe section de l'Ecole pratique des Hautes Etudes. V, Hautes études médiévales et modernes 6. Genève: Droz librairie.

Pacios Lopez, Antonio. 1957. La disputa de Tortosa. I: Estudio historico - critico - doctrinal. Ser.

B, Controversia / Consejo Superior de Investigaciones Científicas. Instituto 'Arias Montano' 6. Madrid/Barcelona: Instituto Arias Montano.

Parrilla, José A., José A. Muñiz and Camilo Caride. 1987. Benedicto XIII: La vida y el tiempo del Papa Luna. Publicación 42. Zaragoza: Caja de Ahorros de la Inmaculada Aragon.

Pereira Pagán, Begoña. 1999. El Papa Luna: Benedicto XIII. Colección El legado de la historia 18. Madrid: Alderabán.

Pillement, Georges. 1955. Pedro de Luna: Le dernier pape d'Avignon. Paris: Hachette.

Planas Badenas, Josefina. 2014. 'Benedicto XIII Y El "Scriptorium” Papal Instalado in Peñiscola: Nuevas Reflexiones'. In Il Codice Miniato in Europa: Libri Per La Chiesa, Per La Città, Per La Corte, eds. Giordana Mariani Canova, Alessandra Perriccioli Saggese and Susan L'Engle. Biblioteca di arte 6. 375-400.

Puig i Puig, Sebastià. 1920. Pedro de Luna: Último papa de Aviñón (1387-1430). Barcelona: Editorial Poliglota.

Rauschenbach, Sina. 2002. 'Josef Albo, Der Messias Und Die Disputation Von Tortosa'. In Medieval Forms of Argument: Disputation and Debate, eds. Georgiana Donavin, Carol Poster and Richard J. Utz. Disputatio: an international transdisciplinary journal of the late Middle Ages 5, Eugene, Oregon: Wipf and Stock. 53-66.

Schwedler, Gerald. 2018. 'Perpignan 1415. Union of Monarchs for the Union of the Church. Diplomatic ceremony between politics and protocol'. In Aymat Catafau, Nikolaus Jaspert and Thomas Wetzstein (eds.) 2018. 443-482.

Seidlmayer, Michael. 1933. 'Peter de Luna (Benedikt XIII.) und die Entstehung des Großen Abendländischen Schismas'. Spanische Forschungen der Görresgesellschaft. Reihe 1. Gesammelte Aufsätze zur Kulturgeschichte Spaniens 4. 206-47.

Seidlmayer, Michael. 1940. Die Anfänge des großen abendländischen Schismas: Studien zur Kirchenpolitik insbesondere der spanischen Staaten und zu den geistigen Kämpfen der Zeit. Münster in Westfalen: Aschendorff.

Sesma Muñoz, José A. 1994. 'De Pedro Martínez de Luna a Benedicto XIII.' In Benedicto XIII, el Papa Luna. Muestra de documentación histórica aragonesa en conmemoración del sexto centenario de la elección papal de don Pedro Martínez de Luna (Aviñón, 28 de septiembre de 1394), ed. idem. Zaragoza: Gobierno de Aragón. 33-46.

Stegmüller, Friedrich. 1963. 'Die Consolatio theologiae des Papstes Pedro de Luna (Benedikt XIII.)', Spanische Forschungen der Görresgesellschaft. Reihe 1. Gesammelte Aufsätze zur Kulturgeschichte Spaniens 21. 209-15.

Suárez Fernández, Luis. 2002. Benedicto XIII: Antipapa o papa? (1328-1423). Barcelona: Ariel. Talmange, Frank. 1985. 'Trauma at Tortosa: The testimony of Abraham Rimoch', Mediaeval Studies 47. 379-415.

Verger, Jacques. 2004. 'Pedro de Luna/ Benoît XIII et l'Université de Montpellier.' In Le Midi et le Grand Schisme d'Occident, eds. Jean-Louis Biget et al. Cahiers de Fanjeaux 39, Toulouse: Centre d'Etudes Historiques de Fanjeaux. 271-89. 